DOI: $10.51384 /$ cert-08.09

\title{
Biró AnNAmÁria*
}

\section{ARISZTOKRATÁK ERDÉLY 18. SZÁZAD VÉGI KULTURÁLIS ÉLETÉBEN. TELEKI SÁMUEL ÉS TELEKI DOMOKOS ELTÉRŐ STRATÉGIÁI}

Kulcsszavak: felvilágosodás; kultúrapártolás; mecénás; kulturális modellek

Dolgozatomban arra teszek kísérletet, hogy egy szerteágazó kulturális tevékenységgel is rendelkező erdélyi és magyarországi arisztokrata család két tagjának tudománypártolói szerepkörére koncentrálva rámutassak azokra a változásokra, amelyek Erdélyben a 18. század végén a tudományos és kulturális életre nagy hatással voltak, az intézményi kereteket pedig nagymértékben meghatározták. Teleki Sámuel (17391822 $)^{1}$ és fia, Teleki Domokos (1773-1798)² annak a gróf széki Teleki családnak voltak a tagjai, amely 1697 óta viselte a római szent birodalmi grófi rangot. A család református ágának legismertebb tagja Teleki Mihály, Teleki Sámuel nagyapja volt, aki I. Apafi Mihály erdélyi fejedelemsége idején volt kancellár, és ő alapozta meg a család későbbiekben felaprózódott vagyonát is. A 17. század második felétôl kezdődően a Teleki család több tagja meghatározó szerepet játszott Erdély közéletében és múvelődéstörténetében. A több nemzedékre visszavezethető minta szerint a családtagok politikai pályát választottak, emellett pedig a tudományos élet, az egyház és az iskola pártfogói voltak. A 18. század a család újbóli fellendülésének időszaka. A század végén többen kastélyépítésekbe kezdenek elsősorban a Marosvásárhelyhez közel fekvő birtokaikon, de Nagybánya környékén is, más családtagok pedig a magyarországi területeken építenek karriert, és rezidenciájukat is idehelyezik.

Teleki Sámuel családi hagyományt követ akkor, amikor erdélyi, főleg magántanítók segítségével történt tanulmányai után peregrinációra indul. Bár gyerekkori könyveiből és tanárainak munkásságából ma már világosabban láthatjuk, hogy - a korábbi

* Biró Annamária (1980), PhD, irodalomtörténész, egyetemi adjunktus, BBTE, BTK, Magyar Irodalomtudományi Intézet, annamaria.biro@ubbcluj.ro.

1 Teleki Sámuel életútját legrészletesebben Deé Nagy Anikó dolgozta fel. Lásd DeÉ Nagy Anikó: A könyvtáralapitó Teleki Sámuel. EME, Kvár, 1997 (a továbbiakban DeÉ Nagy: A könyvtáralapitó).

2 Életútjához lásd Uő: Ifú grófTeleki Domokos. Erdélyi Múzeum LVI(1994).1-2.sz. (a továbbiakban DeÉ Nagy: Iffú gróf). 25-50. 
elképzelésekkel ellentétben - gyerekkorában nem csupán katekézist és latin nyelvet, hanem természettudományokat is tanult, 1759-ben, bázeli tanulmányainak kezdetekor, mégis megrázkódtatásként éli meg, hogy ismeretei mennyire elavultak. ${ }^{3} \mathrm{~A}$ latin nyelv ekkor már visszaszorulóban van, ezért a tényleges tanulmányok megkezdése elôtt németül és franciául kell tanulnia. A korabeli tendenciák mellett ezzel is magyarázhatjuk, hogy inkább a matematikai és természettudományi tárgyakra fekteti a hangsúlyt, és nem a kifinomult nyelvismeretet igénylő bölcsészeti tárgyakra. Bázel és Utrecht után, 1762 és 1763 között öt hónapot tölt Párizsban, ahol nem iratkozik be az egyetemre, hanem társadalmi kapcsolatait építi, és a peregrinációja alatt összegyújtött könyvgyüjteményét gyarapítja. Hazatérve Erdélybe a szokásos gondokkal szembesül: külföldön elsajátított ismereteit nem tudja gyakorlatba ültetni, mert a családi hagyomány miatt számára nem járható a tudományos pálya, hanem birtokügyeivel és erdélyi hivatali ügyeivel kell foglalkoznia. A gazdasága hátramaradott, a családalapítással egy időben építkezésekbe kell kezdenie ahhoz, hogy összegyúlt könyveit egyáltalán elhelyezhesse valahol. Egy ideig még levélkapcsolatban áll külföldi tanáraival, de a mindennapi tennivalók egyre inkább elszakítják a tudományos gondolkodástól. Mindazonáltal olyan változtatásokba kezd, amelyek a következő nemzedéknek adnak nagyobb esélyt az ország modernizálására. 1767-ben a nagyenyedi kollégium főgondnoki tisztségének elvállalásával azt kéri, hogy legyen/lehessen befolyása a tanrend modernizálására. ${ }^{4}$ 1777-től kezdődően hivatali állásokat vállal, előbb Szebenbe költözik mint kormányszéki tanácsos, majd Nagyváradra mint királyi biztos. 1787tôl Bécsben él, előbb alkancellárrá, az erdélyi kancellária 1791-es önállósulását követően pedig kancellárrá nevezik ki, és ezt a tisztséget tölti be haláláig. Nem költözik el Bécsből, onnan irányítja sáromberki birtokát ügyintézői és felesége segítségével, és innen irányítva építteti Marosvásárhelyen a tulajdonképpeni életművének nevezhető könyvtárat is. ${ }^{5} \mathrm{~A}$ gyưjtést peregrinációja idején kezdi, bécsi tartózkodása ideje alatt pedig különböző ügynökök vásárolják számára a könyveket szerte Európában. E tevékenység irányítását Teleki Sámuel soha nem engedi ki a kezéből. A gyújteményt felesége, Bethlen Zsuzsanna magyar nyelvű könyvei egészítik ki, a könyvtárnak helyet adó épületet 1798-ban kezdik el építeni. A tudományok minden ágát felölelő könyvállományt, a ritka nyomtatványok, kéziratok, másolatok gyüjteményét az alapító az 1802 őszére felépült könyvtár egyetlen erre a célra rendelt termében helyezteti

3 Peregrinációs naplóját többször is kiadták: Gróf Teleki Sámuel erdélyi kancellár úti naplója 1759-1763. Kiad. Biás István, bev. Imre Sándor. Marosvásárhely, 1908; Teleki Sámuel peregrinációs naplója. Kiad. Deé Nagy Anikó. Kriterion, Kvár, 2020.

4 Beadványainak egyike megtalálható Marosvásárhelyen a Teleki-Bolyai Könyvtárban. TeleKI Sámuel: Observationes circa Methodum et Materiam Examinorum publicae habendorum. Tf-1157, Ms. 160.

5 Az épületrőll lásd Orbán János: Teleki Sámuel marosvásárhelyi könyvtáráról és gyüjteményeiról. Magyar Könyvszemle CXXXIII(2017). 4. sz. 427-454. 
el. A terem díszítésére Teleki szobrokat és portrékat rendel Mathias Mayer bécsi szobrásztól, Franz Thaller pedig az ő és a felesége mellszobrát készíti el. A kancellár arról is gondoskodik, hogy a könyvtár katalógusa nyomtatásban is megjelenjen, 1796 és 1819 között Bécsben négy kötet lát napvilágot. ${ }^{6} \mathrm{~A}$ mintegy negyvenezer példányból álló könyvgyưjtemény archiválási szándékkal áll össze: a megszerezhető tudás tárháza kíván lenni, így könyvritkaságokon kívül a tudományok minden ágát lefedi a gyújtemény. A francia felvilágosodás legradikálisabb könyvei mellett a felvilágosodás eszméit veszélyesnek tartó kiadványok is megjelennek benne. Így magából a katalógusból csupán olyan jellegü következtetést lehet levonni, hogy Teleki Sámuel igen tájékozott volt, az viszont homályban marad, hogy milyen értékeket és gondolatokat vallott magáénak.

Buzgón támogatta a peregrináló diákokat, az erdélyi iskolákban nem csupán a tananyagra figyelt oda, hanem a könyvtárak fejlesztésével is foglalkozott. Mindezek mellett egy jelentős filológiai érdeme is van: 1784-ben Utrechtben két kötetben megjelentette Janus Pannonius múveinek sokáig legpontosabbnak számító kiadását. ${ }^{7}$

1788-ban ő maga fogalmazza meg hazafiúi hitvallásának lényegét, mely szerint a nemes ember hazafisága a jóra való iparkodásban nyilvánul meg. Számára legfontosabb a közhaszon előmozdítása, a nemzet boldogsága, valamint a tudományok kiterjesztése. Ebbéli fáradozásai jutalmaként több tudós társaság tagjává vagy tiszteleti tagjává választja: elsőként a Societas Regia Scientiarium Göttingensis, majd a Societät für die gesammte Mineralogie zu Jena, a Societas Latina Jenensis stb.

Tevékenységét leginkább Széchényi Ferencéhez lehetne hasonlítani: ahhoz a nemzedékhez tartozott, amely feladatául tűzte ki az ország múveltségbeli felemelését, amit elsősorban a tudományok révén kívánt elérni. A felvilágosodás mint eszmerendszer csak ebben a formájában hatott rá: a természettudományok és általában véve a tudományok képesek lehetnek a változtatásra. Az 1800-as évek elejéről származó jegyzetei szerint társadalmi hovatartozásától függetlenül mindenki lelki és szellemi

6 Bibliothecae Samuelis S.R.I. Com. Teleki de Szék. Pars Prima. Auctores Classicos Graecos et Latinos ex optimis editionibus ordine chronologico [...]. Viennae, 1796; Bibliothecae Samuelis S.R.I. Com. Teleki de Szék. Pars Secunda. Classes Theologicam, Historico-Ecclesiasticam, JuridicoPoliticam, Philosophicam, Philologicam, Antiquariam, Historicam et Litterariam complexa [...]. Viennae, 1800; Bibliothecae Samuelis Com. Teleki de Szék. Pars Tertia. Scriptores Rerum Hungaricam et Transilvanicarum complexa [...]. Viennae, 1811; Bibliothecae Samuelis Com. Teleki de Szék. Pars Quatra. Novas Accessiones [...]. Viennae, 1819. Az ötödik kötetet Deé Nagy Anikó adta ki 2002-ben: Bibliothecae Samuelis Com. Teleki de Szék Pars Quinta, libros inde ab anno MDCCCXIX post typis vulgatam catalogi partem quartam comparatam complexa. Ed. DeÉ Nagy Anikó. Budapestini, 2002.

7 Jani Pannonii Poetarum sui Seculi facile Principis in Hungaria. Quinque Ecclesiarum olim Antistitis Poemata [...]. Traiceti ad Rhenum, 1784; Jani Pannonii Opusculorum Pars altera, in qua exhibentur [...]. Traiecti ad Rhenum, 1784. 
világosságra vágyik. Ennek a gondolatnak kiegészítéseként leszögezi, hogy az emberiség felvilágosításának elengedhetetlen eszköze a „nemzeti nyelv művelése”, tökéletesítése. A dolog ambivalenciáját jelzi viszont, hogy ő maga ezeket a feljegyzéseket németül veti papírra. ${ }^{8}$ Deé Nagy Anikó ezekből a feljegyzésekből azt a következtetést vonja le, hogy Teleki Sámuel érdeklődött a felvilágosodás ideológiája iránt. Jegyzeteiben azonban nem tér el kora jellegzetes kompromisszumos megoldásától: más korabeli szövegekből is ismert érveléssel próbálja közös nevezőre hozni a vallást, az istenhitet a tudományok művelésének szükségességével. Vallás, természettudomány, gazdaságtan, földművelés, kereskedelem és „hasznos művészetek” ismerete egyaránt szükséges a felvilágosult nép számára, állapítja meg a Teleki-monográfia szerzője. ${ }^{9}$ Hozzá tehetnénk azt is, hogy talán nem kimondottan a felvilágosodás foglalkoztatta, hanem az általános, egyfajta enciklopédikus tudás megszerzése miatt olvasta és jegyzetelte a kor filozófusainak írásait, ám meglátásaikat nem tette magáévá. Mecénáskodása és a könyvtár létrehozása révén a felvilágosodás programját követi, ám nem világos, hogy gondolkodásában milyen mértékben fogadta el az ideológia elképzeléseit, hangsúlyozza szintén Deé Nagy Anikó. ${ }^{10} \mathrm{~A}$ felvilágosodás mint ideológia később viszont távol állt tôle, úgy tekintett a fogalomra, mint a radikális politikai nézeteket összefoglaló, sưrítő szimbólumra. Ez a távolságtartás, véleményem szerint, azzal sem oldható fel, hogy sok jakobinussal személyes kapcsolatban állt, vagyis a felvilágosult személyeket nem vetette meg, nem tartotta távol magától. Különösen kancellárként vált konzervatív aulikus arisztokratává, amire a későbbiekben még visszatérek.

Teleki Domokos 1773-ban született Sáromberkén, és 1798-ban, mindössze 25 esztendősen hunyt el Marosvásárhelyen. Természetesen igen nehéz egy életpályát ilyen rövid idő alatt kiteljesíteni, ezért következtetéseink is csak feltételesek lehetnek. A fentiekből láthattuk, hogy édesapja, saját negatív tapasztalataiból adódóan, nagy hangsúlyt fektetett gyermekei (Domokoson kívül Mária és Ferenc érték el a felnőttkort) neveltetésére. A marosvásárhelyi és nagyenyedi kollégiumbeli évek és az erdélyi magántanítók után 1788-tól 1791-ig a bécsi egyetem hallgatója volt. Feltételezhetjük, hogy beteges természete és gyenge testalkata miatt nem ment külföldi peregrinációra. 1791-tôl a pesti egyetemen a magyar törvénykezést is tanulja, nyilvánvaló, hogy apja önmagáéhoz hasonló hivatali karriert képzelt el számára.

Domokos viszont többször is határozottan szembefordul apja akaratával, legelőször a lakhely megválasztása okán:

8 Jegyzetei kéziratban maradtak, ma a Teleki-Bolyai Könyvtár őrzi őket: Excerpta Juridica, Tq-411, Ms. 299.

9 DeÉ NAgY: A könyvtáralapitó. 112.

10 Teleki Sámuel és a Teleki-téka. Kiad.,jegyz. DeÉ Nagy Anikó. Kriterion, Buk., 1976. 34. 
„Azonban valósággal megvallom, hogy Bétsben szolgálatban lenni és lakni teljességgel kedvem nincsen (...) Tudhatja Nagyságod, hogy én a Nagyságod consensusával is ugy gondolkoztam, hogy Magyarországon applicáljam hivatalba magamat sok méltó okokból én most is ugy gondolkodom"11

- írja édesapjának, ezzel hangot adva annak a meggyőződésének is, hogy a nemzeti kultúra szolgálata nem mecénáskodás, hanem tényleges tevékenység révén valósítható meg, az pedig személyes jelenlétet igényel. A magyar jogszokások elsajátítása mellett fogékonynak mutatkozik a gazdasági reformok gyakorlatba ültetésére is, tapasztalatszerzés céljából hazai és külföldi utazásokra indul, az itt készített feljegyzéseit később, 1796-ban meg is jelenteti Egynehány hazai utazások le-irása címmel. ${ }^{12}$ Jóval a szerző halála után, 1805-ben Pesten kiadják Németh László fordításában németül is a szöveget Reisen durch Ungern címmel. A német kiadás nem teljesen hủ fordítása a magyar eredetinek, mivel a közben eltelt 10 év alatt történt változásokat igyekeztek jelezni, és a fordító is javította a hibákat, de a leírásokat nem aktualizálta. Németh László Kazinczy Ferenchez írott leveléből tudjuk, hogy Teleki Sámuel a neki szóló ajánlást a megjelenés előtt átolvasta, és az Aufklärung szó kihagyásával - „minthogy ez most némely fülekben nem jól hangzik" - jóvá is hagyta. A Németh által Kazinczynak is továbbított levélben érzékelhetjük, hogy e döntése során a megfelelési kényszer hajtja Telekit, ugyanis senkivel nem kíván konfliktusba kerülni, még a fia aktualitásukat vesztett meggyőződései miatt sem. ${ }^{13}$ Németh László elkeserítőnek tartja ugyan a fogalmak ilyen szintű kiiktatását a közbeszédből, de a megjelenés érdekében elfogadja a döntést.

Bár a kötetben többnyire tárgyilagos leírásokat olvashatunk, a figyelmes olvasó észreveheti azokat a mintákat, amelyeket az ifjú Teleki Domokos követendőknek vél. Ha az édesapát Széchényi Ferenchez hasonlítottuk, akkor a fiúnál azt kell látnunk, hogy az abszolút példakép Festetics György. A Muraközben járva felhívja a figyelmet az ott található Festetics-birtokok virágzására, és ennek okait keresi:

„G. Festetisch György úr Magyarországban egy a leggazdagabb birtokos urak és egyszersmind egy a legnagyobb gazdák közül. De

11 Idézi DeÉ Nagy: Iffú gróf. 32.

12 Egynébány hazai utazások' le-irása Tót és Horváth országoknak rövid esmértetésével egygyütt, ki adatott G.T.D. által. Wien, 1796. Újabb kiadása: Egynéhány hazai utazások leírása. Tót- és Horvátországoknak rövid esmértetésével együtt. Kiad. EDER Zoltán. Balassi, Bp., 1993 (a továbbiakban Egynéhány hazai utazások).

13 Németh László Kazinczy Ferencnek. Győr, 1804. február 10. Kazinczy Ferencz levelezése. III. Kiad. VÁczy János. MTA, Bp., 1892. 154-156. 
olyan hazafi szívü ökonómus, hogy a gazdaságot és industriát egész erejével nemcsak a maga hasznára való nézve, hanem a közhaszonra és minden birtokai lakosai között nagy igyekezettel elősegíti”. ${ }^{14}$

Azt sem felejti el megemlíteni, hogy bár a földek a földesúr joghatósága alatt vannak, azokat elosztották a lakosok között, akik mint maguk örökös tulajdonát, úgy bírják. A magyar kiadás szerint a grófnak dicséretére szolgál, a német csak mint tárgyilagos folyamatot írja le a tót és horvát lakosság nacionalizálását, magyarrá tételét: „Nagy dicséretire szolgál azonban g. Festetics úrnak, hogy ezt a népet (nb. horvát és tót) nácionálizálni és magyarosítani igyekezik; mely okból magyar oskolákat fundál, és egynéhányat már fundált is". ${ }^{15}$ Több példát is találhatunk arra, hogy a gyakorlatban hogyan próbálta hasznosítani Festetics módszereit: 1796-tól kezdődően kéri apját, hogy adjon át számára egy birtokrészt, ahol megvalósíthatja saját elképzeléseit. Erre azonban nem kerül sor, és a nép életét könnyítő intézkedései minduntalan visszautasításban részesülnek. 1796-ban Bethlen Zsuzsanna így ír erről férjének:

„... ő azt gondolja szegényke, hogy csak az fáról hull a makk, de tudom, ha az maga abroszához törli kését, akkor másként gondolkodik. De ezt csak neked írom édes szívem, ne szólj neki, mert felette megszomorodnék, mivel az néki jó szívétől származik (...) az gabonát és bort igen bőven rendelte, mert 1-sőben az az parancsolatja, hogy mindennap az cselédnek bora járjon. (...) A czigányoknak pedig, mikor dolgoznak úr dolgában, akkor egy nap az magok kenyerin, más napokon pedig az uraság kenyerin dolgozzanak. Minden czigánynak, vagy czigánynénak három czipót adjanak napjára. Az elsőt már eltörlöttem, az másodikat is eltörlöm és az régi szokásra visszateszem őket, mert ezen az módon annyi gabona elmegyen, hogy az ember elijed". ${ }^{16}$

Hasonlóan Festeticshez, a sáromberki iskolaügyet is rendezni kívánja egyrészt a feslett erkölcsű egyháztagok megbüntetése révén, másrészt pedig az iskola matrikulájában olvasható rendelkezések segítségével. Alaposan átgondolt, 19 pontból álló

14 Egynéhány hazai utazások. 110.

15 Uo. 111. A német kiadás szerint: „Der Graf von Festetits sucht sie zu nationalisieren, und stiftet zu diesem Zweck ungarische Schulen unter ihnen, auch die Dorfnotare müssen (...) Ungern sein.” Dominik TELEKI von SzéK: Reisen durch Ungern und einige angränzende Länder. Pesth, 1805. 214-215.

16 Bethlen Zsuzsanna Teleki Sámuelnek. Marosvásárhely, 1796. november 25. MNL OL P 661, Teleki Sámuel oszt., 46. cs., 2908. 
szabályzatról van szó, amelyben kötelezik a szülőket, hogy a gyermekeket ne tartsák vissza az iskolától. Az iskolában nem csupán az erkölcsi nevelés, hanem a nemzeti nevelés alapját is látja, ezért külön is kitér a más vallású és nyelvú gyermekek iskolakötelezettségére: „Az oláh gyermekek is tartozzanak iskolába járni, a mikor azonban a katekizmus taníttatik, akkor kimehetnek, vasárnap sem tartoznak az iskolába menni". ${ }^{17}$

Nyomtatásban még egy munkája jelent meg 1798-ban Bécsben, mely $A$ vallás és erkölts summás tanitása címet viseli, és amely tulajdonképpen egy katekizmus, amelyet Karl Kleynmann és Karl Hilchenbach munkáiból állíthatott össze. ${ }^{18}$ Teleki Domokos kátéja az ifjak tanítását a természettudományos kérdések tisztázásával kezdi. Az égitestek és bolygók, illetve a világban tapasztalható tökéletesség, rend és szépség eredetét vizsgálja, tehát az istenhit kérdéskörét a felvilágosodás megismeréstechnikáihoz köti. Későbbi kritikusai a szöveg problémájaként nevezik meg, hogy nem hitre nevel, hanem racionalizálni kívánja a vallást, tudományos módszerekkel a megértésre és megértetésre törekszik. Ugyancsak a felvilágosodás racionalizmusa, filantropizmusa, vallásitolerancia-vágya mutatkozik meg abban, ahogy a szerző tárgyát kezeli a $A s p a-$ nyolok Mexicóba címú kéziratban maradt drámájában. ${ }^{19} \mathrm{~A}$ szöveg kiadását a korabeli cenzor visszautasította, nem annyira ideológiai, mint inkább dramaturgiai és nyelvi kérdésekre hivatkozva. A 2019-es kiadás sajtó alá rendezője szerint a kényes téma feldolgozása során nem válik sematikussá a bemutatás: noha a szerző egyértelmúen a bennszülöttek pártján áll, közöttük is láttatja a politikailag kockázatos széthúzást, az eredendő bűnöket, a tlascalaiak leigázását és így elégedetlenségük kiváltását, a nagyok közötti őszinteség (voltaképpen a felelős nyelvi viselkedés) hiányát, amely szintén katasztrófához vezet. Hasonlóképpen törekszik arra, hogy a spanyolok között is különböző viszonyulásformákat mutasson ki, és ezáltal minél több szereplőjét tegye emberileg egyénítetté. Ez a törekvés újdonságnak számít a kor magyar színjátszásában.

Teleki Domokos esetében egy kifejlődőben levő tudós szerzői életpálya ér véget korai halálával. Ennek bizonyítéka az is, hogy az ásványtani gyüjteménye miatt a Societaet für die gesammte Mineralogie zu Jena elnökévé választja. ${ }^{20}$ Gondolkodás-

17 Idézi DeÉ NaGy: Ifúu grớf. 43.

18 Kolumbán Vilmos József: Iff. Teleki Domokos kátéforditása. Studia Doctorum Theologiae Protestantis. A Kolozsvári Protestáns Teológia Kutatóintézetének kötetei 4(2013). 201212.

19 A drámaszöveg csupán 2019-ben vált a nagyközönség számára is hozzáférhetővé. I. G. Teleki Domokos: A Spanyolok Mexicoba. S. a. r. Egyed Emese. EME, Kvár, 2019 (Erdélyi drámatéka 1). A drámáról lásd még Egyed Emese: A Spanyolok Mexicóba (Plurális világok) = Uó: Láttató világok. Mentor, Marosvásárhely, 2014. 175-181.

20 Ehhez lásd Viczián István-DeÉ Nagy Anikó: Domokos Teleki, der erste Präsident der "Societät für die gesammte Mineralogie zu Jena" = Deutsche und ungarische Mineralogen in Jena. 
módját láthatóan a felvilágosodás eszmerendszere határozta meg, cselekvésstratégiái pedig erős akaratáról tesznek tanúbizonyságot. Teleki Sámuel többször hangot ad nemtetszésének fia döntései miatt, de ezekben a döntésekben nem látja az eszmei hátteret, csupán az akaratos jellemet. A köztük levő feszültségekről feleségének az alábbiakat írja:

„Úgy látom, hogy Domokosnak a házasodásábanis az a leg nagyobb akadály, a mi egyéb Világi szerencséibenis gátot köt; hogy tudni illik ő mindenben a maga tettzését, akarattyát, és planumát teszi és veszi szint mértékül; azt kívánván, hogy minden ahoz szabja magát, ő pedig a más akarattyát ne kövesse. Ennek oka az: hogy ő azt tarttya, hogy jobban lát másnál, egyenesebben ítél másnál, és a mint neki tettzik, úgy leg jobb. Azért csak azokhoz vagyon confidentiája, a kik dicsérik és helybe hadgyák, a mit ő akar. Gyermekségitől fogva tapasztalván ezen tulajdonságát, sokszor meg intettem rólla; de soha nem convincalhattam arról, hogy nekem vagyon Rechtem. Mint Atyának ugyan mutatott engedelmességet, de nem meg-győződésből, hanem kötelességből. Bővölködik mindenben a maga ítéleteivel, az én ítéletemre pedig azokban a dolgokban sem hajlik, a mellyekben meg őszültem. A Világot még nem ösmeri, mégis azt tartya, hogy az emberek engemet csalnak meg inkább, mint őtet, és a gazdasághozis, cseléd-tartáshoz, háztartáshoz, Jószágbeli rendeléshez s.a.t. többet tud nállamnál”. ${ }^{21}$

A mecénási szerepkör és a cselekvő tudós, tudományszervező szerepköre az apa és a fiú, valamint az Erdélyi Magyar Nyelvmívelő Társaság esetében is megmutatkozik. A titkár, Aranka György az alapítás idején - ahogyan ezt egy Prónay Sándornak írott levelében kifejti - gyanakvóan tekint Teleki Sámuelre, aki szerinte megakadályozta a társaság megindításának engedélyezését. Jó érzékkel vonja be a támogatók körébe az elölülőnek kinevezett erdélyi gubernátort, Bánffy Györgyöt, akinek hatalma viszont, véleménye szerint, nem ér el Bécsig, és akinek Telekivel való kapcsolata is ambivalens; bár ez a történet még nincs kellőképpen feldolgozva. Aranka tulajdonképpen már a kezdetektôl a maga oldalára szerette volna állítani Teleki Sámuel kancellárt is. Teleki 1791-es levélben üdvözli Aranka buzgólkodását, de türelemre és a megfelelő idő kivárására inti:

Wissenstransfer an der Wende des 18-19. Jahrhunderts im Rahmen der „Societät für die gesammte Mineralogie zu Jena“. Szerk. Gurka Dezső. Gondolat, Bp., 2015. 30-48.

21 Teleki Sámuel Bethlen Zsuzsannának. Bécs, 1797. február 24. MNL OL P 661, Teleki Sámuel oszt., 46. cs., 2645. 
„örömmel értettem az Urnak Kőz-jóra tőrekedő igyekezetének Tárgyait; mellyeknek tehettségem szerint elö-mozditásokra tulajdon gyüjteményebőlis készségemet ajánlom; csak a mostani fel-hevúlésnek, mértékletesebb hangja a szelidebb Musákat szollani engedje”.22

Láthatjuk tehát, hogy Teleki az ún. reformországgyúlések után nem olyan lelkes, mint sok, szebb idők eljövetelében reménykedő honfitársa. Teleki óvatossága ebben is hasonlatos Széchényi Ferenc álláspontjához, aki támogatta ugyan Pálóczi Horváth Ádám társaságalapító szándékát, ám a gyúléseket veszélyesnek látta, és szorgalmazta a levelek általi kapcsolattartást. ${ }^{23}$ Teleki Sámuel 1795-ig nem játszik szerepet a Társaság múködésében, ekkor pedig Arankának hosszan kell magyarázkodnia arról, hogy köze van-e az ő társaságának a jakobinus összeesküvésekhez. Aranka meg akarja menteni társaságát a titkos összeesküvés vádjától, ezért határolódik el Bánffy Györgytől is, aki viszont magára vállalja az erdélyi szervezkedő nemesség védelmét. Aranka ekkor teljes mértékben Teleki Sámuel vonzáskörébe irányítja a társaságot, tudományos tevékenységüket az ô oltalmába ajánlja. ${ }^{24}$ Úgy tűnik, döntése inkább pozitív, semmint negatív hatásokkal volt a társaság múködésére. Az 1795-1797-es időszak a fellendülést hozza. Megjelenik a társaság első kötete, a gyúléseken egyre inkább tudományos kérdésekkel foglalkoznak, gyarapodik a gyújtemény, aminek következtében egyre több levelező tag jelzi belépési szándékát a társaságba. A rendelkezésünkre álló levéladatok szerint ifj. Teleki Domokossal, a kancellár fiával Aranka 1795-ben veszi fel a kapcsolatot, és bízza meg különböző kisebb feladatokkal. ${ }^{25} \mathrm{Az}$ ifjú gróf először az 1796. október 13-án tartott gyúlésen vesz részt személyesen, és már itt fontos küldetéssel látják el: a novemberi pozsonyi országgyülésen a Nyelvművelő Társaság képviseletében szerezzen újabb tagokat a tudományokban elért érdemeik alapján, rendre, vallásra, nemzetiségre való tekintet nélkül. ${ }^{26}$ Jancsó

22 Teleki Sámuel Aranka Györgynek. Bécs, 1791. május 30. OSZK, Kézirattár, QuartHung, 1994, 161.

23 Széchényi Ferenc és Pálóczi Horváth Ádám kapcsolatához lásd Lengyel Réka: „Egy titkos, de azonban nem alattomban való nyelvmüvelö társaság". Pálóczi Horváth Ádám kiadatlan levele (1789) és tudóstársaság-tervezete = Magyar Arión: Tanulmányok Pálóczi Horváth Ádám müveiröl. Szerk. Csörsz Rumen István-Hegedüs Béla. Reciti, Bp., 2011.33-39.

24 Ugyancsak tôle reméli saját sorsának jobbra fordulását is: állandó jellegú állást szeretne a Királyi Táblán, hogy anyagilag is fenntarthassa a sok levelezést és szövegmásoltatást kívánó tevékenységét. Többször emlegetett óhaja nemsokára meg is valósul. Lásd pl. Aranka György Teleki Sámuelnek. Marosvásárhely, 1795. augusztus 1. MNL OL P 32, Teleki Sámuel osztály, 13-14.

25 A levelezést lásd CsứRY Bálint: Aranka Györgyhöz irt ismeretlen levelek. Irodalomtörténeti Közlemények XLV(1935). 1. sz. 34-58.

26 A gyúlés jegyzőkönyvét lásd Jancsó Elemér: Az Erdélyi Magyar Nyelvmüveló Társaság iratai. Akadémiai, Buk., 1955. 215. 
Elemér közli Teleki Domokos következő év márciusi jelentését erről a megbízatásáról, melyből az derül ki, hogy saját - senkivel nem egyeztetett - döntése értelmében Schedius Lajost felkérte magyarországi fő levelezőnek úgy, hogy rendelkezésére bocsátotta a taglistát, és a tagok besorolásában olyan új rendszert dolgozott ki, amely megkülönbözteti a tényleges tudományos munkát végző tagokat a csupán anyagi hozzájárulást biztosítóktól. ${ }^{27} 1797$ januárjában Teleki Domokos írásbeli megbízást küldött Schediusnak, melyben egyrészt elküldte a Teleki Mihály aláírásával ellátott jegyzőkönyvet, másrészt feladatait is kijelölte:

„azon Társaságnak Magyar Országon Fő Correnspondense, és mint egy Secretariussa légyen. Ezen fel vállalandó hivatalja az Urnak főképpen abban fog állani, hogy a' Magyar Országi Membrumokkal Correspondeálván, a tőllők magához küldetendő minden Munkákat akár Manuscriptumban, akár Nyomtatásban; nem külőmben a’ bé küldetendő természeti Productumokat, Mesterségi darabokat Pénzeket kezéhez vegye s azokról Protocollumot tartván, azután bizonyos alkalmatosság által Marus Vásárhelyre a’ Társaság Fó Secretariussához bé küldesse". ${ }^{28}$

1797 júniusában újabb jelentést nyújt be, ${ }^{29}$ melyben részben a tagok rendszerezésének bevezetését sürgeti, másrészt a teljes társaság szerkezetének megváltoztatását szorgalmazza, nem csupán a társaság, hanem a kormányzó előtt is. Az átszervezés következtében szétválasztaná a munkás társaság ügyeit a teljes társaság ügyvitelétől és pénzügyeitől, ennek intézésére egy kisebb csoportosulást választván, amelynek titkára különbözne a tudományos ügyek intézésére kinevezett titkártól. E pozíció betöltésére minden bizonnyal önmagát látta a megfelelő személynek. 1797 júliusában a következőket írja Bánffy György gubernátornak:

„Még azt akarom alázatoson jelenteni Excellentziádnak: hogy az a' kérdés v: nehézség jővén elő itt közöttünk 's hogy ha Excellenciád a’ Társaság kis Tanáttsát ki nevezni méltoztatik, ki lenne az a' ki a Secretáriusi Hivatalt fel vállalná? (minthogy az a' leg utolsó v. leg iffjabb membrumott illetné) én declaráltam, hogy ha külömben

27 If. Gr. Teleki Domokos jelentése = Jancsó: i. m. 223-225.

28 Uo. 153.

29 Uo. 229-230. 
Excád engemet azon dirigens membrumok közzé nevezni méltoztatik, az emlitett terhet magamra fel vállalom”. ${ }^{30}$

Aranka Györgynek méltán lehetett tehát az az érzése, hogy a társaság vezetése kicsúszik a kezei közül, ezért hamarosan közbelépett, és Teleki Domokost, aki láthatólag nem az apjától tanult minta alapján lép fel mecénásként, hanem tevékenyen részt kíván venni a társaság életében, félreállítja.

Annak ellenére, hogy történnek kísérletek Aranka részéről is a társaság megújítására, a Nyelvmívelő Társaság szerkezetének megváltoztatása elkerülhetetlennek tû́nik. Nem Teleki Domokos viszi ugyan véghez, őt ugyanis egyre inkább kiszorítják a belső ügyekből. Ma már nehéz eldönteni, hogy ebben a félreállításban nagyobb súlya annak volt-e, hogy Aranka féltette pozícióját, vagy inkább annak, hogy Teleki Sámuel határozottan kérte beteges természetú fiának a tennivalók alóli felmentését. 1798 márciusában Teleki aggódó levelet indít Arankához, amely aggodalom - amint Domokos fiának ugyanazon év szeptemberében bekövetkezett halála mutatja - nem volt alaptalan. ${ }^{31}$

Halála miatt Teleki Domokos dolgos életpályáját nem tudta kiteljesíteni, így nem láthatjuk, hogy mennyiben lett volna az más, mint az apjáé, aki a hagyományos mecénási szerepet a könyvtáralapítással és filológiai munkákkal próbálta kiegészíteni. Ennek megítélése azonban a korban nem egyértelmúen volt pozitív. Egy, az 1800-as évek elején írott, Erdély politikusait és a haza érdekében tett cselekedeteiket számba vevő paszkvillus ugyanis Telekin éppen a cselekvést kéri számon a tudósokra tartozó könyvolvasás helyett. „Passiokkal tellyes Imperialis Golya / Groff Teleki Samuel csak a' könyvet bujja" - írja minden valószínűség szerint Szacsvay Sándor. A testi adottságaira utaló „gólya” jelző gyakran jelenik meg egy-egy negatív jelző kíséretében a róla szóló - nem feltétlenül a tágabb közönségnek szánt - szövegekben. A jakobinusösszeesküvés kapcsán perbe fogott Barcsay Ábrahám is meg van győződve róla, hogy Teleki azért sem segít neki a vádak alóli tisztázásban, és azért viselkedik ellenségesen vele, mert az elkobzott levelekben vén gólyának nevezte, így személyes bosszúállásként értelmezi a jogi eljárásban betöltött szerepét. ${ }^{32}$

30 Teleki Domokos levele Bánffy Györgyhöz. Marosvásárhely, 1797. július 17. Jancsó Elemér másolatában az OSZK Kézirattárában.

31 Teleki Sámuel levele Aranka Györgyhöz. Bécs, 1798. március 12. Csűry: i. m. 48. „Domokos fiam már le-ment Erdélyben, és tudom hogy hogy ('́gy!) neki nagy tüze és buzgosága vagyon a Tudos Tarsasag munkálkodásának gyarapittására; de physicuma és temperamentuma nem ahoz valo lévén, minthogy a sok ülés, olvasás, irást, és intensio egésségének nagy ártalmára vagyon, valamint személyesenn, ugy mostanis, hozzám és Házamhoz való jószivüségére Kérem az Urat, hogy arra neki alkalmatosságot ne engedjen. Ha lassan siet messzeb jút, ha kevesebbre igyekezik többre érkezik.”

32 DeÉ Nagy: A könyvtáralapitó. 128. 
Teleki Sámuel könyvek iránti szeretetének máig fennmaradt példája a Marosvásárhelyen található könyvtár, amelyben Teleki Domokos kéziratban maradt hagyatéka is fellelhető. A két életpálya nem állítható szembe olyan élesen egymással, mint ahogyan azt a fentiekben tettem, de itt most azt kíséreltem meg nyomatékosan érzékeltetni, hogy a politikai szerepvállalás gyakran a tudósi szerepkört is kijelölheti. Az viszont nyilvánvaló, hogy apa és fiú esetében nagyon eltérő kultúrtámogatási modellek érvényesülnek, amelyeknek kialakulására nem feltétlenül a személyes habitus volt a legnagyobb hatással, hanem a korszak megváltozott intézményi és társadalmi keretei. Teleki Domokos ahhoz a nemzedékhez tartozott, amelyik a felvilágosodást nem életidegen ideológiaként recipiálta, hanem cselekvési formaként applikálta. Rövid életpályája annak a példája, ahogyan társadalomjobbító szándékait több területen birtokigazgatás, oktatás, kultúra, intézményalapítás - is bevezeti. Teleki Sámuel egy korábbi, jól bevált minta szerint építette fel életét és karrierjét, hazája stabilizálását és fejlesztését birodalmi keretek között látta megvalósíthatónak, mecénásként támogatta a kulturális intézményeket, és olyan könyvtárat hozott létre, amelyik a következő generációk számára biztosíthatta a tudás megszerzésének feltételeit. Apa és fiú életútjában a célok tehát nem álltak távol egymástól, a megvalósítás módjáról való elképzeléseik azonban időnként más-más utakra terelték őket, miközben mindketten nagyrabecsüléssel nyilatkoztak egymás eredményeiről.

\section{ARISTOCRATS IN THE CULTURAL LIFE OF TRANSYLVANIA AT THE END OF THE $18^{\text {TH }}$ CENTURY. THE DIFFERENT STRATEGIES OF SÁMUEL TELEKI AND DOMOKOS TELEKI}

\section{Keywords: enlightenment; cultural advocacy; patronage; cultural models}

Even before his election as Chancellor of Transylvania, Sámuel Teleki (1739-1822) placed special emphasis on supporting Transylvanian cultural aspirations. Following his peregrination to Basel, he pursued a political career, and in the meantime started the preparatory works for building his library in Târgu Mureş. Even after moving to Vienna he followed the Transylvanian academic efforts, although from this point his patronage often depended on political decisions, like in the case of the events in Transylvania from 1794-1795. His son, Domokos Teleki (1773-1798) wanted to participate in the cultural transition from the end of the eighteenth century not only as a patron or supporter, but by proving his dedication to the academic societies through his activity as an organiser and by scholarly works. In my presentation I compare the activities of these two figures to shed light on the differing strategies aristocrats followed at the end of the eighteenth century. 


\section{ARISTOCRATTI ÎN VIAȚA CULTURALĂ A TRANSILVANIEI LA SFÂRȘITUL SECOLULUI AL XVIII-LEA. STRATEGIILE DIFERITE ALE LUI SÁMUEL TELEKI ȘI DOMOKOS TELEKI}

\section{Cuvinte-cheie: iluminism; patronaj cultural; mecenatură; modele culturale}

Sámuel Teleki (1739-1822), cancelar al Transilvaniei începând cu anul 1791, a pus un accent deosebit pe susținerea aspirațiilor culturale transilvănene chiar înainte de alegerea sa în funcția de cancelar. După studii efectuate în Basel se întoarce în Transilvania, și în paralel cu îndeplinirea diferitelor funcții instituționale, începe lucrările de întemeiere a unei biblioteci la Târgu Mureș. Odată numit vice-cancelar, apoi cancelar, s-a mutat la Viena, dar a continuat să monitorizeze aspirațiile științifice transilvănene. Patronajul său a depins însă adesea de decizii politice, ca în cazul evenimentelor din Transilvania din anii 1794-1795. Fiul său, Domokos Teleki (1773-1798) nu a vrut să asiste la schimbările culturale de la sfârșitul secolului al XVIII-lea doar din postura de susținător aristocrat, ci s-a implicat în activitatea societăților științifice prin activități organizatorice și prin muncă științifică. Studiul de față prezintă activitățile culturale ale celor doi, după care evidențiază diferitele strategii de acțiune ale aristocraților de la sfârșitul secolului al XVIII-lea. 